\title{
Menjadi Berdaya dan Mandiri; Pengelolaan Dana Zakat oleh Mustahik di Provinsi Riau
}

\section{Becoming Empowered and Independent; Zakah Fund Management by Mustahik in Riau Province}

\author{
M. Agus Noorbani \\ Balai Litbang Agama Jakarta \\ Email: agusbaca@gmail.com \\ Artikel diterima 29 Mei 2019, diseleksi 23 Oktober 2019, \\ dan disetujui 10 Desember2019
}

Abstract: This paper presents the results of research on the management of zakat funds by mustahiks in Riau Province. This qualitative study uses a case study design that examines the management of zakat funds in four zakat institutions, BAZNAS Kota Pekanbaru, BAZNAS Siak Regency, LAZ Ibadurrahman Kabupaten Bengkalis, and LAZ Swadaya Ummah Pekanbaru. The results of this study found that most of the beneficiary mustahik for productive economic programs had not experienced an increase in the standard of living that was good enough or prosperous. The success rate of this program in each zakat institution can be estimated to be in the range of less than $20 \%$. The efforts made by the mustahik in utilizing the assistance of zakat institutions are mostly carried out intuitively and have not been programmed on an sustainability basis in the development of a productive economy. Muzakki who distributed ZIS funds to Baznas more civil servants, whereas muzakki who channel their ZIS funds to zakat institutions that are managed by the community are diverse individual muzakki or small, medium, or even large-scale companies.

Keywords: zakat, empowering, productive economy, Riau 
Abstract: This paper presents the results of research on the management of zakat funds by mustahiks in Riau Province. This qualitative study uses a case study design that examines the management of zakat funds in four zakat institutions, BAZNAS Kota Pekanbaru, BAZNAS Siak Regency, LAZ Ibadurrahman Kabupaten Bengkalis, and LAZ Swadaya Ummah Pekanbaru. The results of this study found that most of the beneficiary mustahik for productive economic programs had not experienced an increase in the standard of living that was good enough or prosperous. The success rate of this program in each zakat institution can be estimated to be in the range of less than 20\%. The efforts made by the mustahik in utilizing the assistance of zakat institutions are mostly carried out intuitively and have not been programmed on an sustainability basis in the development of a productive economy. Muzakki who distributed ZIS funds to Baznas more civil servants, whereas muzakki who channel their ZIS funds to zakat institutions that are managed by the community are diverse individual muzakki or small, medium, or even large-scale companies.

Keywords: zakat, empowering, productive economy, Riau

\section{A. Pendahuluan}

Indonesia merupakan negara dengan populasi penduduk terbesar keempat di dunia, setelah Republik Rakyat Cina, India, dan Amerika Serikat. Dalam laporan Perserikatan Bangsa-bangsa (PBB) berjudul World Population Prospects, ${ }^{1}$ jumlah penduduk Indonesia pada tahun 2015 mencapai 258 juta jiwa. Jumlah ini meningkat sekitar 20 juta jiwa, jika mengacu pada hasil Sensus Badan Pusat Statistik (BPS) tahun 2010, di mana penduduk Indonesia 5 tahun yang lalu berjumlah 238 juta jiwa. ${ }^{2}$ Pertumbuhan penduduk yang pesat dalam beberapa aspek memberi keuntungan dengan meningkatnya sumber daya manusia. ${ }^{3}$ Beriringan dengan itu juga disertai tumbuhnya permasalahan sosial. Akumulasi penduduk pada daerah tertentu dengan sendirinya menciptakan kompetisi dalam lapangan kerja dan sumber daya ekonomi. Ketatnya 
kompetisi kemudian memunculkan gesekan-gesekan antar kelompok maupun individu. ${ }^{4}$

Permasalahan sosial akibat kepadatan penduduk di Indonesia akan semakin meningkat jika pelaksanaan pembangunan tidak berjalan merata, di mana pembangunan hanya menjangkau wilayah-wilayah perkotaan sementara perdesaan dibiarkan. Sehingga meningkatkan arus migrasi penduduk dari desa ke kota atau dari daerah-daerah yang tidak tersentuh pembangunan ke wilayah yang tersentuh pembangunan. Arus migrasi penduduk ini bukan tidak mungkin memunculkan permasalahan sosial, terutama adalah kemiskinan.

Pada bulan September 2015, jumlah penduduk miskin di Indonesia mencapai 28,51 juta jiwa atau $11,13 \%$ dari total populasi penduduk Indonesia. Jumlah ini mengalami peningkatan 0,08 juta jiwa dari Maret tahun yang sama, di mana pada Maret 2015 jumlah penduduk miskin di Indonesia berjumlah 28,59 juta jiwa. Berdasarkan persebarannya menurut wilayah, penduduk miskin di wilayah perdesaan merupakan kantong kemiskinan terbesar dibanding wilayah perkotaan. ${ }^{5}$ Penyebab naik-turunnya angka kemiskinan ini biasanya disebabkan oleh stabilitas harga bahan pokok terutama makanan. Sebagai negara yang banyak dari penduduknya menghabiskan sebagian besar pendapatannya untuk bahan makanan, terutama beras, maka kenaikan harga bahan makanan memiliki konsekuensi bagi mereka yang miskin atau berada di dekat garis kemiskinan. ${ }^{6}$

Pemerintah sendiri bukan tidak melakukan apapun untuk mengentaskan masalah kemiskinan ini. Pada Rencana Pembangunan Jangka Menengah Nasional (RPJMN) 2010-2014, pemerintah membuat strategi pengentasan kemiskinan yang terdiri dari tiga kelompok; pertama adalah bantuan sosial, yang menyediakan bantuan langsung bagi keluarga miskin agar mereka dapat memenuhi kebutuhan dasar mereka. Kelompok kedua, pemberdayaan komunitas yang tujuannya menyediakan dana sosial bagi komunitas miskin yang dapat mereka gunakan untuk kebutuhan dasar sosial dan pelayanan ekonomi sesuai dengan prioritas 
kebutuhan mereka. Kelompok ketiga adalah pemberdayaan usaha kecil yang tujuannya adalah menyediakan kemudahan mendapatkan kredit untuk membuka usaha kecil tanpa terganggu oleh berbagai persyaratan hutang-piutang. ${ }^{7}$

Harapan dari strategi ini adalah penduduk miskin yang menjadi penerima bantuan sosial pada kelompok 1 akan mengalami peningkatan kesejahteraan kemudian akan beralih menjadi kelompok ke-2, yang pada akhrinya mereka dapat ikut serta dalam kelompok ke-3 dan membuka usaha sendiri. Evaluasi dari strategi ini menunjukkan hasil yang beragam pada setiap kelompok, terutama akibat sulitnya mencapai target bantuan dan akibat selalu terdampak kenaikan harga makanan. ${ }^{8}$ Sayangnya, program-program bantuan yang sifatnya langsung ini, kerapkali tidak merata kepada seluruh penduduk miskin atau bahkan tidak tepat sasaran. Beik ${ }^{9}$ menyatakan bahwa bantuan sosial yang bersifat langsung diberikan kepada penduduk miskin seringkali tidak efektif akibat koordinasi dan manajemen penyaluran bantuan yang kurang baik. Diperlukan alternatif lain dan intervensi yang sangat signifikan untuk mengentaskan problem kemiskinan di negara ini.

Presiden Soesilo Bambang Yudoyono (SBY), pada tahun 2011, memerintahkan untuk menjadikan zakat sebagai jalur ketiga pengentasan kemiskinan, disamping dua program lain, yaitu program ekonomi dan bantuan pro rakyat. Menurutnya, zakat akan menjadi jalur ketiga yang akan memperkuat upaya mengurangi kemiskinan. ${ }^{10}$ Survei yang dilakukan tim Indonesia Magnificence of Zakat (IMZ) terhadap 821 rumah tangga di Jabodetabek dari total 4.646 populasi rumah tangga penerima dana zakat menghasilkan temuan berkurangnya jumlah kemiskinan menjadi 10,79\%. Rata-rata pendapatan rumah tangga miskin terhadap garis kemiskinan juga dapat diperkecil menjadi 4,69\%. Selain itu, intervensi zakat juga mampu mengurangi kedalaman kemiskinan sebesar 12,12 hingga 15\%. Yang kesemuanya bermakna bahwa zakat mampu mengurangi beban rumah tangga sehingga perekonomian rumah tangga miskin menjadi lebih ringan. ${ }^{11}$ 
Berbagai temuan dari beberapa kajian mengenai peran zakat dalam mengurangi kemiskinan yang telah dipaparkan di atas baru menyajikan secara kuantitaif peningkatan pendapatan mustahik (penerima zakat) dan pengurangan jumlah penduduk miskin penerima zakat. Menjadi pertanyaan kemudian adalah apakah pendapatan mustahik akan terus mengalami peningkatan dan apakah jumlah penduduk miskin akan terus berkurang jika bantuan dana zakat dihentikan? Beberapa kajian mengkonfirmasi bahwa meski secara teoritis zakat, infak, dan shadakah dapat mengurangi kemiskinan, namun realitasnya jumlah orang miskin tidak berkurang, bahkan cenderung bertambah.

Mustapha dalam kajiannya di Malaysia pada awal 1980an menemukan bahwa tidak berkurangnya angka penduduk kemiskinan meski penyaluran dana zakat rutin dilaksanakan akibat distribusi yang menyimpang. Kajiannya menemukan bahwa hanya 11\% hingga 13\% dari seluruh dana zakat yang diberikan kepada penduduk miskin yang berhak, sisanya disalurkan kepada amil dan para tokoh agama. Hasil yang sama ditemukan di Pakistan, di mana dana zakat yang terkumpul oleh negara gagal mengentaskan kemiskinan akibat birokrasi yang terlalu korup. ${ }^{12}$

Timur Kuran memberikan analisis yang lebih baik mengenai mengapa zakat sampai saat ini belum mampu mengentaskan kemiskinan di negara-negara Islam atau berpenduduk muslim terbesar. Menurutnya, setelah melakukan riset di beberapa negara dengan penduduk mayoritas beragama Islam, zakat sejauh ini tidak memberikan dampak berarti bagi penduduk miskin dan ketimpangan sosial. Sebab, zakat masih ditafsirkan secara konservatif. Zakat belum dimaksimalkan untuk mengelola asetaset seperti tanah maupun aset-aset fisik lainnya. ${ }^{13}$

Berbagai kajian yang menelaah tentang filantropi Islam di Indonesia telah banyak dilakukan, baik yang dilakukan oleh para sarjana dan pihak-pihak lain di dalam negeri maupun dari luar Indonesia.Meski telah banyak ditelaah, istilah filantropi Islam sendiri baru mulai banyak 
dikenal di kalangan sarjana dan ilmuwan Indonesia pada decade 1990an akhir, bersamaan dengan datangnya era reformasi.Sebelumnya, di Indonesia lebih banyak dikenal kajian mengenai zakat, infak, dan sedekah. ${ }^{14}$

Center for The Study of Religion and Culture (CSRC) UIN Syarif Hidayatullah Jakarta beberapa kali melakukan kajian mengenai aktivisme filantropi Islam di Indonesia. Tahun 2005, lembaga ini melakukan riset mengenai lembaga zakat dan wakaf yang ada di Indonesia. Kajian yang dilakukan di sepuluh lembaga filantropi Islam ini menemukan bahwa otoritas agama masih sangat kuat melegitimasi wacana dan praktik filantropi Islam di Indonesia. Tradisi filantropi Islam masih kuat dipengaruhi oleh motif dan tujuan keagamaan yang dipahami dalam rangka ketundukkan pada doktrin ajaran agama secara klasik, yaitu untuk beribadah dan mendekatkan diri kepada Tuhan. ${ }^{15}$

Kajian lain yang dilakukan terhadap lembaga pengumpul dan pengelola zakat dilakukan oleh HilmanLatief. Hasil kajiannya yang menelaah mengenai pengelolaan dana zakat, infak, dan sedekah (ZIS) di Pesantren Darul Ulum, Galur menemukan bahwa masyarakat mempercayakan pengelolaan dana ZIS kepada pihak pesantren. Sementara pesantren memiliki kebebasan penuh untuk menyalurkan dana ZIS yang terkumpul. Pada akhirnya, terjadi kohesivitas yang kuat antara pesantren dan masyarakat. ${ }^{16}$

Aktivisme filantropi Islam di Indonesia telah banyak menjadi kajian berbagai sarjana di Indonesia. Penelitian yang dilakukan Kholis, dkk., di Yogyakarta misalnya menghasilkan temuan bahwa beberapa lembaga pengumpul dan pengelola zakat mengandalkan pemotongan gaji dalam strategi pengumpulan dananya (fund raising), dan ada juga yang mengandalkan kreativitas program dan akuntabilitas lembaga dalam menarik minat muzakki. Dana yang terkumpul tersebut disalurkan dalam berbagai bentuk, ada yang langsung diberikan kepada mustahik maupun diberikan dalam bentuk program pemberdayaan masyarakat. 
Makhrus dan Utami, berdasarkan penelitian terhadap Badan Amil Zakat (BAZ) dan Lembaga Amil Zakat Muhammadiyah (LAZMU) Kabupaten Banyumas, mendapati peran lembaga filantropi Islam dalam mengoptimalkan pemberdayaan masyarakat di Kabupaten Banyumas dilakukan secara variatif. Pemberdayaan yang dilakukan meliputi dua bentuk yakni pemberdayaan terhadap pihak donatur (muzakki) dengan memberikan pelayanan optimal. Hal tersebut terlihat pada pengelolaan filantropi Islam pada BAZNAS dan LAZISMU Kabupaten dalam bentuk layanan jemput zakat, website, media jejaring sosial, dan lainnya. Sedangkan penyaluran dana filantropi Islam disalurkan dalam beragam bentuk program pemberdayaan masyarakat yang memungkinkan para mustahik untuk bisa mengakses dengan cara proses dan prosedur yang harus dipenuhi. Realisasi program lembaga filantropi Islam dalam melakukan pemberdayaan masyarakat di Kabupaten Banyumas sebagaimana telah dipraktikkan oleh BAZNAS dan LAZISMU Kabupaten Banyumas direaliasasikan dalam bentuk pelatihan dan bantuan modal baik berupa hibah maupun dana bergulir. Selain itu, adapula kegiatan penyaluran dalam bentuk charity seperti, bantuan pendidikan, bantuan pelayanan kesehatan, bantuan sarana dan prasana ibadah dan lainnya. ${ }^{17}$

Kajian mengenai perundang-undangan di bidang filantropi juga sudah banyak dilakukan. Kajian yang dilakukan Widyawati misalnya mendapati bahwa meski telah banyak peraturan zakat yang dikeluarkan pemerintah, namun pengelolaan zakat masih tumpang tindih karena tidak menyeluruh.Meski demikian, dikeluarkannya peraturan mengenai zakat dan wakaf menunjukkan bahwa pemerintah Indonesia tidak abai terhadap filantropi keagamaan dan menegasikan bahwa Indonesia adalah negara yang murni sekular. ${ }^{18}$

Kajian yang lebih komprehensif dilakukan oleh Public Interest Research and Advocacy Center (PIRAC) pada tahun 2000. Riset yang mengintegarasikan metode kuantitatif dan kualitatif ini menyurvei 2.500 orang di 11 kota/kabupaten di 11 propinsi yang terdapat di lima pulau utama di Indonesia, yaitu Jawa, Sumatera, Sulawesi, Kalimantan, dan Bali. 
Kajian ini menelaah aktivisme filantropi yang dilakukan oleh penduduk Indonesia yang berasal dari berbagai agama, disertai kajian mengenai lembaga filantropi keagamaan yang ada di Indonesia. Salah satu hasil temuan kajian PIRAC ini adalah bahwa 96\% responden menyatakan bahwa mereka memberikan langsung bantuan kepada masyarakat yang membutuhkan dan sebagian besar, $87 \%$, penerima donasi tersebut adalah para pengemis. ${ }^{19}$

Pada tahun 2010, Dompet Dhuafa Republika melakukan penelitian dengan menggunakan data dari Badan Pusat Statistik (BPS) untuk menghitung potensi muzakki dan mustahik.Dengan menggunakan berbagai indikator seperti potensi desa, tingkat pendapatan, batas garis kemiskinan, dan indikator-indikator kesejahteraan penduduk lainnya penelitian ini menghasilkan sebuah data penting mengenai persebaran mustahik dan muzakki yang ada di Indonesia.Gambar 1 di bawah ini menyajikan Peta Muzakki, Mustahik, dan Potensi Wilayah di Indonesia. Hasil kajian yang dilakukan Dompet Dhuafa Republika ini menunjukkan bahwa Indonesia bagian Barat, terutama Pulau Jawa dan Sumatera memiliki potensi wilayah yang tinggi, serta muzakki dan mustahik yang juga tinggi.Sementara di Indonesia bagian Timur, potensi wilayah tergolong rendah, menunjukkan minimnya infrastruktur daerah, termasuk muzakki dan mustahik yang ada, karena banyak penduduk non-muslimdi wilayah ini. ${ }^{20}$

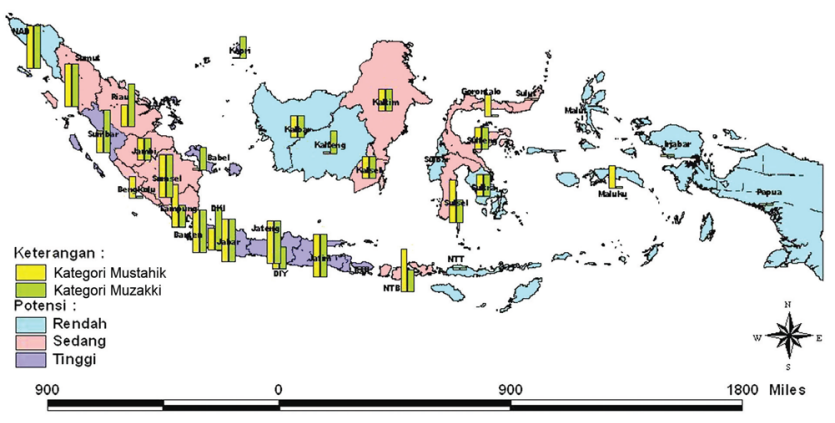

Gambar 1.

Peta Muzakki, Mustahik, dan Potensi Wilayah di Indonesia 
Kementerian Agama melalui Badan Litbang dan Diklat serta Balai Litbang Agama (BLA) Jakarta, selaku unit pelaksana teknis (UPT) juga pernah melakukan penelitian mengenai tema ini. BLA Jakarta, ${ }^{21}$ misalnya, pernah melakukan penelitian mengenai pengelolaan zakat produktif yang dikumpulkan dari karyawan-karyawan Badan Usaha Milik Negara (BUMN). Penelitian ini lebih memfokuskan penyaluran dana zakat dari karyawan BUMN kepada mustahik. Kajian terbaru yang dilakukan oleh Kementerian Agama adalah kajian yang dilakukan Badan Litbang dan Diklat ${ }^{22}$ mengenai keberadaan organisasi pengelola zakat pasca peninjauan kembali (judicial review) Undang-undang Nomor 23 Tahun 2011.

Beberapa hasil penelitian yang telah dikemukakan sebelumnya, sebagian besar menelaah peran lembaga zakat, peraturan di bidang zakat, fungsi zakat dalam pengentasan kemiskinan maupun peningkatan kesejahteraan penduduk, dan persebaran mustahik dan muzakki baik yang menggunakan metode kualitatif maupun kuantitatif. Penelitian ini bergerak ke arah menindaklanjuti berbagai kajian yang telah disajikan di atas, yang berusaha memberikan gambaran mengenai muzakki dan mustahik di beberapa wilayah di Indonesia. Penelitian ini terutama adalah berusaha menelaah usaha-usaha yang dilakukan para mustahik untuk lepas dari status mustahik.

Berdasarkan latar belakang dan permasalahan yang telah dikemukakan di atas, secara umum penelitian ini bertujuan untuk;

1. Mengetahui gambaran kehidupan mustahik sebelum dan sesudah menerima dana dari lembaga zakat.

2. Mengetahui usaha yang dilakukan mustahik untuk mengembangkan dana zakat yang diberikan.

3. Mengetahui para donatur yang menyumbangkan dana ZIS mereka ke lembaga-lembaga zakat. 
Penggunaan istilah pemberdayaan kerap berkaitan dengan kelompokkelompok yang terpinggrikan, seperti perempuan dan kaum miskin. ${ }^{23}$ Pemberdayaan masyarakat, dalam sejarahnya, merupakan sebuah gerakan perlawanan pembangunan sebagai alternatif dari hegemoni pembangunanisme (developmentalism). Sejak tiga dekade silam, ahli pembangunan berhaluan kritis telah melontarkan pertanyaan besar, mengapa terjadi kemiskinan di tengah-tengah gencarnya proyek-proyek pembangunan ${ }^{24}$

Rapaport $^{25}$ menyatakan bahwa pemberdayaan merupakan peningkatan kemampuan masyarakat untuk mengelola kehidupan mereka sendiri. A.K. Sen ${ }^{26}$ menekankan pemberdayaan pada ranah individu, yang mencirikan pemberdayaan sebagai kebebasan yang dimiliki seseorang untuk melakukan dan mencapai tujuan-tujuannya. Pemberdayaan masyarakat umumnya dirancang dan dilaksanakan secara komprehensif. Bank Pembangunan Asia (ADB) $)^{27}$ menjelaskan bahwa, pemberdayaan dikatakan komprehensif jika memiliki karakteristik; berbasis lokal, berorientasi pada kesejahteraan, berbasis kemitraan, berlangsung secara holistik, dan berkelanjutan.

Bank Dunia (World Bank) menarik konsep pemberdayaan pada peran dan norma institusi dan struktur sosial dan politik, di mana para pelakunya membuat dan berusaha menggapai pilihan-pilihan mereka. Berdasarkan ini, Bank Dunia mengukur pemberdayaan berdasarkan pada; keberadaan pilihan, penggunaan pilihan, dan pencapaian pilihan. ${ }^{28}$ Cochran meyakini bahwa masyarakat memahami apa yang mereka butuhkan jauh lebih baik dari siapapun. Karenanya, pemberdayaan harus dipahami sebagai sebuah proses perubahan yang berkelanjutan. ${ }^{29}$

Pemberdayaan memiliki dua kecenderungan, pertama bahwa proses pemberdayaan menekankan pada proses memberikan atau mengalihkan sebagian kekuasan, kekuatan atau kemampuan kepada masyarakat agar menjadi lebih berdaya. Proses ini disertai dengan upaya penyediaan aset yang dapat mendukung kemandirian mereka. Kecenderungan pertama 
ini disebut dengan kecenderungan primer. Kecenderungan yang kedua adalah apa yang diperkenalkan Paulo Freire sebagai konsientisasi (conscientization), yaitu proses pemahaman dan penumbuhan kesadaran terhadap situasi yang sedang terjadi, baik dalam kaitannya dengan relasirelasi politik, ekonomi, dan sosial. Masyarakat bisa dikatakan berhasil memasuki konsientisasi adalah pada saat mereka mampu menganalisis masalah mereka, mengidentifikasi penyebabnya, dan memperoleh pengetahuan baru secara mandiri. ${ }^{30}$

Filantropi berasal dari bahasa Yunani philanthropia yang berarti cinta terhadap atau sesama manusia (philos atau philo yang berarti cinta dan anthropos yang berarti manusia). ${ }^{31}$ Filantropi kadang disamakan dengan charity atau amal (dalam bahasa Indonesia kini diserap sebagai karitas yang berasal dari Bahasa Latin caritas) yang memiliki makna hampir serupa, yakni cinta tak bersyarat. Namun demikian, terdapat perbedaan di antara kedua istilah tersebut.Filantropi memiliki cakupan makna yang lebih luas.Jika filantropi merupakan cinta yang didasarkan pada upaya menyelidiki sebab utama persoalan, maka karitas merupakan pemberian jangka pendek. Filantropi bersifat progresif, gerakannya terencana dengan tujuan yang terukur serta melibatkan organisasi, baik pemerintah maupun swasta, dan prakarsa swadaya masyarakat, sedangkan karitas bersifat individual, sporadis, dan pengelolaannya bersifat konvensional. ${ }^{32}$ Secara harfiah, filantropi adalah konseptualisasi dari praktik memberi, pelayanan, dan asosiasi secara sukarela untuk membantu pihak lain yang membutuhkan sebagai ekspresi rasa cinta. ${ }^{33}$

Filantropi merupakan konsep yang universal, telah dipraktikkan ribuan tahun lamanya di setiap budaya dan bangsa. ${ }^{34}$ Dalam sejarah Yunani misalnya, Platon diketahui memberikan tanah produktifnya untuk wakaf bagi lembaga Akademia yang didirikannya. Dalam berbagai tradisi agama, praktik filantropi juga sudah dikenal lama, baik dalam tradisi agama-agama yang berkembang di Timur Tengah semacam Yahudi, Kristen, dan Islam pun pada agama-agama yang berkembang di wilayah lain seperti Hindu dan Buddha di India, agama-agama dan 
kepercayaan di Afrika dan Amerika, dan wilayah lainnya. ${ }^{35}$ Meskipun filantropi dalam praktiknya ada di berbagai daerah sesuai dengan tradisi dan budaya, secara falsafi konsep ini tidak dimaknaisama dalam berbagai budaya. ${ }^{36}$

Filantropi sebagai salah satu modal sosial telah menyatu di dalam kultur komunal (tradisi) yang telah mengakar sejak lama khususnya di masyarakat perdesaan Indonesia. Fakta kultural menunjukkan bahwa tradisi filantropi dilestarikan melalui pemberian derma kepada teman, keluarga, dan tetangga yang kurang beruntung. Di perdesaan Jawa dikenal tradisi gotong royong dalam berbagai aktivitas. Di tanah Sunda, juga dikenal tradisi "parelek", di Padang dikenal tradisi "julo-julo", dan tradisi yang sama juga dikenal di Suku Dayak sebagai "sa'alent". Kesemua tradisi di atas mengacu pada semangat membantu sesama atau menyediakan harta dan tenaga untuk kepentingan orang lain secara sukarela seperti pernikahan, pemakaman jenazah, pembangunan jembatan, hingga pembangunan rumah. ${ }^{37}$

James O. Midgley ${ }^{38}$ menyatakan bahwa filantropi merupakan satu dari tiga pendekatan untuk meningkatkan kesejahteraan, bersama dengan pelayanan sosial dan kerja sosial. Menurut sifatnya dikenal dua bentuk filantropi, yaitu filantropi tradisional dan filantropi untu keadilan sosial (social justice). Filantropi tradisional pada umumnya berbentuk pemberian langsung seperti memenuhi kebutuhan makanan, tempat tinggal, dan sebagainya. Orientasi filantropi tradisional lebih bersifat individual. Model filantropi semacam ini justru mempertebal relasi kuasa antara si kaya dan si miskin. Model filantropi tradisional hanya mampu mengobati penyakit kemiskinan akibat dari ketidakadilan struktur. $^{39}$

Filantropi keadilan sosial, pada sisi yang berlawanan dari yang tradisional, merupakan bentuk kedermawanan sosial yang dimaksudkan untuk menjembatani jurang antara si kaya dan si miskin. Substansi filantropi keadilan sosial berorientasi pada perubahan institusional 
dan sistematik. Sumberdaya yang terkumpul ditujukan untuk kegiatan yang mengarah pada perubahan sosial. Metode utama perubahan sosial adalah pengorganisasian masyarakat, advokasi, dan pendidikan publik. ${ }^{40}$ Pada Tabel 1. di bawah ini secara singkat disajikan perbedaan filantropi tradisional dan keadilan sosial;

Tabel 1.

Perbedaan Filantropi Tradisional dan Filantropi untuk Keadilan Sosial

\begin{tabular}{lll}
\hline & \multicolumn{1}{c}{ Filantropi Tradisional } & Filantropi Keadilan Sosial \\
\hline Motif & Individual & Publik, kolektif \\
Orientasi & Kebutuhan mendesak & Kebutuhan jangka panjang \\
Bentuk & Pelayanan sosial langsung & $\begin{array}{l}\text { Mendukung perubahan sosial } \\
\text { Sifat }\end{array}$ \\
Tindakan yang berulang-ulang & $\begin{array}{l}\text { Kegiatan menyelesaikan } \\
\text { ketidakadilan struktur }\end{array}$ \\
Dampak & $\begin{array}{l}\text { Mengatasi gejala ketidakadilan } \\
\text { social }\end{array}$ & $\begin{array}{l}\text { Mengobati akar penyebab } \\
\text { ketidakadilan sosial }\end{array}$ \\
Contoh & $\begin{array}{l}\text { Menyediakan tempat tinggal } \\
\text { bagi tuna wisma }\end{array}$ & $\begin{array}{l}\text { Advokasi perundang- } \\
\text { undangan, perubahan } \\
\text { kebijakan publik }\end{array}$ \\
\hline
\end{tabular}

Sumber: Prihatna, 2005; 5

Agama Islam memiliki ajaran mengenai filantropi. Bahkan, ajaran filantropi dianggap sangat penting dalam Islam sehingga kewajiban mengeluarkan sebagian harta bagi yang membutuhkan, yang dikenal dengan zakat, menjadi salah satu pilar utama dari lima pilar agama yang disebut Rukun Islam. ${ }^{41}$ Islam, seperti ajaran agama lainnya, sangat menentang ketidakadilan distribusi sumber-sumber material. Beberapa ajaran yang terdapat di dalam agama ini, berkaitan dengan usaha mengurangi, meski tidak sampai menghilangkan, ketimpangan sosial dan ekonomi. ${ }^{42}$

Filantropi Islam digali dari dua sumber hukum utama yang menjadi pegangan seluruh umat Islam di dunia, yaitu Al-Quran dan Sunnah Rasulullah SAW. Di dalam Al-Quran Surat Al-Hasyr ayat 7 ditekankan 
pentingnya pendistribusian harta, "agar harta itu jangan beredar di antara orang-orang kaya saja di antara kamu". Jika ayat 7 Surat AlHasyr berbicara dalam konteks rampasan perang, maka dalam surat At-Taubah ayat 60 secara rinci disebutkan, bahwa "sesungguhnya yang berhak menerima zakat (sedekah) adalah orang yang fakir, orang-orang miskin, pengelola zakat, para mu'allaf yang dibujuk hatinya, untuk (memerdekakan) budak, orang-orang yang memiliki hutang, mereka yang menempuh jalan Allah, dan untuk mereka yang sedang dalam perjalanan jauh. Zakat yang ditentukan tersebut merupakan suatu ketetapan yang diwajibkan Allah".

Prihatna menjabarkan bahwa perspektif Al-Quran mengenai praktik filantropi ini berakar pada ideal-ideal esensial berikut; pertama, bahwa di dalam Islam tidak ada pembedaan antara usaha-usaha spiritual dan material dalam kehidupan manusia; kedua, filantropi merupakan karakter, tujuan, dan fungsi komunitas muslim; ketiga, adanya konsep perwalian kekayaan dan properti di dalam ajaran Islam. Tujuan filantropi Islam adalah menjamin tegaknya keadilan sosial yang merupakan pesan utama ajaran Islam.Secara spiritual tujuan filantropi Islam adalah membersihkan harta dan menyucikan jiwa. ${ }^{43}$ Di dalam Surat At-Taubah ayat 103, tujuan filantropi ini dijelaskan, "Ambillah zakat (sedekah) dari sebagian harta mereka. Yang dengan zakat tersebut dapat membersihkan (harta) dan menyucikan (jiwa) mereka". Harta harus dibersihkan karena di dalamnya melekat hak orang lain. Praktik ini akan menyucikan diri dari sifat tamak, kikir, dan kecintaan berlebihan kepada harta. ${ }^{44}$

Riaz Hassan menyatakan bahwa terdapat tiga instrumen utama filantropi Islam untuk pemerataan kesejahteraan masyarakat, yaitu sedekah, zakat, dan wakaf.Tradisi-tradisi ini telah terbentuk bersamaan dengan hadirnya Islam di muka bumi.Di dalam penelitian ini, aktivisme yang menjadi bagian dari filantropi keagamaan yang menjadi fokus utama kajian adalah zakat, infak, dan sedekah.Wakaf tidak menjadi bagian dari kajian ini, karena dibutuhkan kajian tersendiri dengan pendekatan dan analisis yang berbeda. ${ }^{45}$ 


\section{Zakat, Mustahik, Muzakki, dan Pendayagunaan Zakat}

Zakat, infak, dan sedekah dalam Al-Quran mengandung pengertian yang sama dan acapkali digunakan secara bergantian untuk maksud yang sama, yaitu berderma. Pada Surat At-Taubah ayat 60, yang sering dirujuk sebagai dalil mengenai kewajiban berzakat dan golongan penerimanya misalnya, tidak menyebutkan kata zakat melainkan kata sedekah. Namun pada tataran penggunaan ketiga istilah ini, terkandung makna khusus dan digunakan secara berbeda. ${ }^{46}$

Zakat secara bahasa berarti suci, baik, tumbuh, dan terpuji. Jika dikatakan bahwa sesuatu itu zaka, maka artinya tumbuh dan berkembang. Jika seseorang itu zaka, maka ia baik dan terpuji. ${ }^{47}$ Dalam Al-Quran Surat AS-Syams ayat 9 misalnya, dikatakan bahwa "Sungguh sangat beruntung orang-orang yang telah menyucikannya", yang bermakna bahwa orang-orang yang telah menunaikan zakat, maka dirinya telah menyucikan, mengembangkan, dan memperbaiki diri dan hartanya.Zakat dalam istilah fikih bermakna "sejumlah harta tertentu yang diwajibkan Allah diserahkan kepada orang-orang yang berhak", di sampin makna zakat adalah juga "mengeluarkan jumlah tertentu itu sendiri". Ibnu Taimiah berkata bahwa jiwa orang yang berzakat itu menjadi bersih dan kekayaannya akan bersih pula. ${ }^{48}$

Al-Zuhayly mengutip beberapa definisi yang dikemukakan oleh para fuqaha' menyatakan bahwa zakat setidaknya mengandung unsur; mengeluarkan sebagian harta agar memberi manfaat bagi orang lain, harta yang yang dikeluarkan merupakan bagian yang khusus yaitu bagian harta yang telah mencapai nishab sesuai syariat, harta tersebut dikeluarkan pada waktu-waktu khusus yakni saat harta sudah sempurna kepemilikan dalam satu tahun atau dikeluarkan pada saat menjelang Idul Fitri, dan perilaku tersebut dihukumi wajib. Jadi menurut Zuhayly, zakat merupakan penunaian hak yang wajib karena Allah yang terdapat dalam harta seorang muslim untuk diberikan kepada mustahik. Zakat kerap dinamakan sedekah karena perbuatan tersebut akan menunjukkan 
kebenaran seorang hamba dalam beribadah dan ketaatan kepada Allah SWT. ${ }^{49}$

Undang-undang Nomor 23 Tahun 2011 (UU no. 23 2011) pada pasal 1 membedakan definisi antara zakat, infak, dan sedekah (ZIS). Dalam undang-undang tersebut, yang dimaksud zakat adalah harta yang wajib dikeluarkan oleh seorang muslim atau badan usaha untuk diberikan kepada yang berhak menerimanya sesuai dengan syariat Islam. Sedangkan infak adalah harta yang dikeluarkan oleh seseorang atau badan usaha di luar zakat untuk kemaslahatan umum. Sedekah adalah harta atau non-harta yang dikeluarkan oleh seseorang atau badan usaha di luar zakat untuk kemaslahatan umum. Definisi tersebut belum jelas benar membedakan apa yang dimaksud zakat, infak, dan sedekah. Definisi ZIS dalam UU no. 232011 tersebut lebih jauh telah mengenakan kewajiban ZIS tidak hanya pada individu melainkan juga kepada kelompok (perusahaan atau badan usaha).

Al-Quran surat At-Taubah ayat 60 merupakan dalil rujukan untuk menentukan sesiapa yang berhak menerima zakat. Mereka ini secara Bahasa disebut sebagai mustahik (orang yang berhak). Dalam ayat tersebut dijelaskan 8 kelompok (ashnaf) mustahik yang berhak menerima zakat. Ayat tersebut berbunyi, "sesungguhnya zakat-zakat (yang kau keluarkan diperuntukkan) hanya untuk orang-orang fakir, orang miskin, pengelola zakat (amil), para mualaf (orang yang baru masuk agama Islam) yang dibujuk hatinya, (digunakan) untuk memerdekakan budak, orang-orang yang berhutang, untuk mereka yang berjuang di jalan Allah, dan orang-orang yang sedang dalam perjalanan. (Zakat tersebut merupakan) suatu ketetapan yang diwajibkan oleh Allah dan Allah Maha Mengetahui lagi Maha Bijaksana". Dalam UU no. 232011 pasal 1 ayat 6, hanya dijelaskan bahwa mustahik adalah orang yang berhak menerima zakat. Undang-undang tersebut tidak lebih jauh lagi mendefinisikan kategori mustahik kriteria prioritas penerima.

Yusuf Qardawi berpendapat, bahwa sasaran pertama zakat adalah hendak menghapus kemelaratan dan kemiskinan, karenanya kedua 
kelompok pertama inilah, fakir dan miskin, yang memiliki priroritas lebih dibanding 6 kelompok lainnya di dalam Al-Quran.Beliau juga bersandar pada hadits Rasulullah SAW saat menugaskan salah seorang sahabatnya ke Yaman; “Ajarakanlah kepada mereka, bahwa mereka dikenakan zakat, yang akan diambil dari orang kaya dan diberikan kepada golongan miskin". ${ }^{50}$

Sementara itu, muzakki dalam UU no. 232011 pasal 1 ayat 5 didefinisikan sebagai seorang muslim atau badan usaha yang berkewajiban menunaikan zakat. Qardawi menyatakan bahwa orang yang wajib zakat adalah seorang muslim dewasa yang waras, merdeka, dan memiliki kekayaan dalam jumlah tertentu dengan syarat-syarat tertentu pula. Zakat tidak diwajibkan kepada selain muslim karena zakat merupakan satu dari lima pilar utama Islam, sehingga orang yang dianggap kafir tidak mungkin diminta melakukannya. ${ }^{51}$

Permasalahan pengelolaan dan pendistribusian zakat, infak, dan sedekah di Indonesia hampir serupa dengan permasalahan yang dihadapi negara dengan penduduk mayoritas muslim lainnya. Beik (dalam Republika, 2012) menyatakan bahwa kurang optimalnya zakat di Indonesia dalam mengentaskan kemiskinan karena 4 hal; pertama adalah kualitas sumberdaya manusia dalam mengelola dan memberdayakan dana zakat. Kedua, masih jauhnya rentang antara potensi dana zakat dengan dana zakat yang terkumpul. ${ }^{52}$ Mengenai potensi dana zakat, infak, dan sedekah (ZIS) di Indonesia masih terjadi perbedaan pendapat. Hasil riset CSRCUIN pada 2008, potensi danaZIS di Indonesia dapat mencapai Rp. 19.3 triliun, sementara yang baru terserap hanya 5\%-7\% saja. ${ }^{53}$ Pada tahun 2004, hasil estimasi yang dilakukan oleh Timur Kuran (dalam Hassan, 2007; 28) dana tunai dari filantropi Islam yang terkumpul di Indonesia mencapai US $\$ 1.65$ miliar, yang sebagian besarnya berasal dari zakat. Ketua Badan Amil Zakat Nasional (BAZNAS), DidinHafidudin menyatakan, bahwa zakat yang terkumpul di Indonesia pada tahun 2010 mencapai 1,5 triliun, meningkat dari tahun 2009 yang sebesar 1,2 triliun. ${ }^{54}$ 
Alasan ketiga belum optimalnya zakat mengentaskan kemiskinan di Indonesia adalah regulasi yang berbeda-beda di setiap daerah di Indonesia. Selain regulasi, stabilitas politik di masing-masing daerah juga memberi dampak pada pengumpulan dan penyaluran dana zakat kepada penduduk miskin. Alasan keempat, masih banyak umat Islam di Indonesia yang beranggapan bahwa menyalurkan zakat langsung kepada mustahik lebih afdhal daripada melalui lembaga atau amil. Kepastian penyalurannya pun terjamin tanpa was-was disalahgunakan. Selain itu, zakat di Indonesia juga lebih banyak disalurkan untuk kepentingan konsumtif dibandingkan produktif. ${ }^{55}$

Sudewo menjelaskan bahwa setidaknya kita bisa menelaah empat perspesi mengapa ZIS, di Indonesia khususnya, kerap tidak produktif dan lebih banyak ke pola konsumtif. Pertama, tidak produktif; ZIS yang dibagikan selama ini cepat habis usai dibagikan karena pendekatan pola konsumtif yang masih terlalu mendominasi.Kedua, mubazir; dana besar yang dapat dihimpun dari ZIS tidak dikelola sebagai modal untuk mengubah fakir miskin. Padahal, dengan potensi danaZIS yang ada, akan ada banyak sentra-sentra industri yang bisa terbangun dan menyerap tenaga kerja. Ketiga, lenyapnya profesionalitas; dengan potensi besar dari dana ZIS yang ada, namun lekas habis karena pola konsumtif, baik Baznas maupun LAZ melenyapkan kesempatan melatih diri menjadi lembaga keuangan yang mumpuni dan profesional (Baitul Mal). Keempat, kekeliruan cara pandang; selama ini, banyaknya pendekatan konsumtif dalam penyaluran zakat dianggap sebagai salah satu upaya terbaik. Alasannya sebagai upaya melipatgandakan pahala dan yang diinginkan para muzakki. Akan mengkhawatirkan jika pada suatu saat memproduktifkan zakat dianggap samadengan menahan kebajikan zakat. Jika keempat cara pandang di atas masih tertanam, upaya meningkatkan taraf hidup dan melepaskan kaum fakir miskin dari jerat kenestapaan, yang merupakan tujuan utama zakat, tidak akan terwujud. ${ }^{56}$ 
Undang-undang nomor 23 tahun 2011 dalam Pasal 27 menegaskan bahwa zakat dapat didayagunakan untuk usaha produktif dalam rangka penanganam fakir miskin dan peningkatan kualitas umat. Kementerian Agama Republik Indonesia (RI), melalui Direktorat Pemberdayaan Zakat (Ditberkat) Direktorat Jenderal Bimbingan Masyarakat Islam (Ditjen Bimas Islam) telah mengeluarkan sebuah buku panduan, khususnya, bagi lembaga-lembaga zakat untuk mengembangkan model usaha bagi para mustahik. Hal ini menyiratkan bahwa Kementerian Agama RI berusaha mengembangkan pengelolaan zakat menggunakan pendekatan yang tidak hanya konsumtif, namun lebih jauh ke arah produktif.

Prosedur utama dalam pengembangan usaha produktif bagi para mustahik adalah;

1. Studi kelayakan dan penentuan area. Pada point ini ditetapkan indikator-indikator penilaian kelayakan sebagai mustahik.

2. Analisis program pemberdayaan dan kelayakan usaha. Dalam bagian analisis ini, para pengelola ZIS mesti pandai dalam melihat tujuan dari usaha yang akan dirintis; kejelasan usaha, perencanaan, berjangka panjang, memberi kemaslahatan bagi masyarakat, dan terutama adalah dapat memberdayakan si mustahik atau kelompok mustahik.

3. Monitoring dan evaluasi program. Bagian ini dapat dilaksanakan dengan kerjsama antara pengelola ZIS dengan pihak lain yang kompeten. Bisa saja diberikan kursus dan pendampingan dari Kementerian Koperasi dan Usaha Kecil Menengah, Kementerian Pertanian, para wirausahawan yang telah berhasil, dan sebagainya.

4. Pelaporan pelaksanaan program. ${ }^{57}$

Penelitian ini merupakan penelitian kualitatif dengan rancangan studi kasus yang berusaha menjabarkan profil mustahik dan muzakkidi Propinsi Riau. Data yang digunakan dalam menganalisis permasalahan penelitian ini berasal dari sumber primer dan skunder. Sumber primer 
didapat dari wawancara terhadap informan-informan kunci dan observasi. Informan kunci yang dimaksud terutama adalah mustahik yang menjadi sampel berjumlah 2-3 orang. Mustahik dalam penelitian ini adalah mereka yang menerima dana bantuan zakat yang kemudian dikembangkan untuk modal usaha sehingga mampu mengubah kondisi kehidupan mereka. Informan berikutnya adalah pengelola badan atau lembaga zakat untuk menggali berbagai program yang dikembangkan untuk memberdayakan dana zakat yang terkumpul. Informan selanjutnya adalah pihak pemerintah untuk mengetahui kebijakan mengenai pengentasan kemiskinan di wilayah dimaksud serta berbagai kebijakan mengenai pendayagunaan dana zakat, infak, dan sedekah. Sumber data skunder didapat dari dokumen-dokumen kependudukan, gambaran potensi dan pendapatan daerah penelitian, dan sebagainya yang berkenaan dengan kesejahteraan. Juga dokumen-dokumen mengenai potensi dan penyeluran zakat, infak, dan sedekah, persebaran distribusi zakat, infak, dan sedekah, dan berbagai dokumen lain berkenaan dengan zakat, infak, dan sedekah. Pengumpulan data menggunakan daftar pertanyaan wawancara terbuka dan lembar observasi.

Penelitian lapangan ini dilakukan selama 25 hari di empat lembaga zakat yang terdapat di tiga kabupaten/kota di Propinsi Riau, yaitu BAZNAS Kota Pekanbaru, BAZNAS Kabupaten Siak, LAZ Ibadurrahman Kabupaten Bengkalis, dan LAZ Swadaya Ummah Kota Pekanbaru. Setiap institusi dipilih dengan mempertimbangkan karakteristik lembaga. BAZNAS Kota Pekanbaru mewakili lembaga pengelola zakat pemerintah yang beroperasi di ibukota propinsi dan BAZNAS Kabupaten Siak mewakili lembaga pengelola zakat di daerah. Kedua lembaga pengelola zakat pemerintah ini juga merupakan dua lembaga yang telah memiliki manajemen yang baik. Sedangkan LAZ Ibadurrahman Bengkalis dipilih sebagai lembaga zakat milik swasta yang berada di daerah dan LAZ Swadaya Ummah merupakan lembaga zakat milik swasta yang berloksi di ibukota propinsi. Kedua lembaga zakat ini juga hanya beroperasi di wilayah Propinsi Riau. 


\section{B. Hasil dan Pembahasan}

Propinsi Riau merupakan propinsi yang memiliki sepuluh kabupaten dan dua kotamadya, dengan ibukotanya terletak di Kota Pekanbaru. Propinsi ini merupakan daerah daratan dengan ketinggian wilayah dari permukaan laut sangat rendah. Rerata wilayah di Propinsi Riau adalah 18,25 meter di atas permukaan laut (mdpl). Daratan tertinggi terletak di Pasir Pengarayan yang berada di ketinggian $91 \mathrm{mdpl}$, sedangkan yang terrendah terletak di Selat Panjang dengan ketinggian 2 mdpl. ${ }^{58}$

Jumlah penduduk propinsi ini, berdasarkan Sensus Penduduk tahun 2010, berjumlah 5.538.367 jiwa, terdiri dari 2.853.168 jiwa penduduk laki-laki dan 2.685.199 jiwa penduduk perempuan. Distribusi penduduk terkosentrasi di Kota Pekanbaru dengan komposisi 16.34\% dari seluruh penduduk yang ada di Propinsi Riau atau 1.011.467 jiwa. Jumlah penduduk terkecil terdapat di Kabupaten Kepulauan Meranti, sebanyak 179.894 jiwa.Propinsi Riau merupakan salah satu daerah tujuan transmigrasi nasional.Pada tahun 2013, jumlah transmigran yang ditempatkan di propinsi ini sebanyak 30 kepala keluarga atau 115 jiwa. ${ }^{59}$

Tabel 2.

Komposisi Penduduk Berdasarkan Agama di Setiap Kabupaten/Kota

\begin{tabular}{llccccccrr}
\hline \multirow{2}{*}{ No } & Kabupaten/ & \multicolumn{7}{c}{ Penduduk } \\
\cline { 2 - 9 } & Kota & Jumlah ${ }^{60}$ & Jumlah & Islam & Kristen & Katolik Hindu & Buddha & Khonghucu \\
\hline 1 & KuantanSingingi & 291,324 & 291,324 & 280,478 & 9,614 & 814 & 23 & 378 & 17 \\
2 & Indragiri Hulu & 3,624 & 362,400 & 336,394 & 19,753 & 3,845 & 14 & 1,058 & 1,336 \\
3 & Indragiri Hilir & 661,142 & 661,142 & 649,827 & 6,119 & 603 & 75 & 4,294 & 224 \\
4 & Pelalawan & 301,253 & 301,253 & 253,465 & 42,123 & 2,947 & 86 & 2,619 & 13 \\
5 & Siak & 375,238 & 375,238 & 311,820 & 54,250 & 5,010 & 226 & 3,601 & 331 \\
6 & Kampar & 68,771 & 687,710 & 620,465 & 61,613 & 5,098 & 54 & 450 & 30 \\
7 & Rokan Hulu & 474,457 & 474,457 & 400,125 & 69,355 & 4,700 & 16 & 231 & 30 \\
8 & Bengkalis & 497,261 & 497,261 & 411,569 & 56,295 & 4,624 & 85 & 24,286 & 402 \\
9 & Rokan Hilir & 551,706 & 551,706 & 480,505 & 51,696 & 3,355 & 87 & 15,095 & 968 \\
10 & Kepulauan Meranti & 176,187 & 158,601 & 148,888 & 2,350 & 1,755 & 57 & 5,129 & 422 \\
11 & Pekanbaru & $1,140,511$ & $1,163,246$ & $1,040,345$ & 51,843 & 22,758 & 3,221 & 44,769 & 310 \\
12 & Dumai & 251,205 & 256,899 & 217,288 & 29,165 & 5,700 & 68 & 4,256 & 422 \\
\hline
\end{tabular}




\begin{tabular}{ccccccccc}
\hline Total & $5,770,394$ & $5,781,237$ & $5,151,169$ & 454,176 & 61,209 & 4,012 & 106,166 & 4,505 \\
\hline$\%$ & & $100 \%$ & $89 \%$ & $8 \%$ & $1 \%$ & $0.1 \%$ & $2 \%$ & $0.1 \%$ \\
\hline
\end{tabular}

Sumber: Riau dalam Angka 2015, BPS Propinsi Riau.

Jumlah penduduk miskin Propinsi Riau pada tahun 2015 sebanyak 562.920 jiwa atau $8.82 \%$ dari seluruh penduduk yang ada di propinsi ini. ${ }^{61}$ Jumlah ini meningkat dari tahun sebelumnya yang hanya berjumlah 498.300 jiwa atau $7.99 \%$. $^{62}$ Penyebab kenaikan jumlah penduduk miskin ini salah satunya adalah kebakaran hutan yang menimbulkan bencana asap di propinsi tersebut pada tahun 2015. Indeks pembangunan manusia (IPM) propinsi ini termasuk yang tertinggi kedua di Indonesia setelah Propinsi Kepulauan Riau, yaitu 70,33 pada tahun 2014. Kota Pekanbaru menjadi kota dengan IPM tertinggi di Propinsi Riau dengan indeks sebesar 78,42. IPM ini bahkan lebih tinggi dari rerata IPM nasional yang sebesar $68,9 .{ }^{63}$

Sebagai daerah yang disinggahi banyak pendatang, karena merupakan daerah perniagaan, menjadikan Propinsi Riau sebagai wilayah yang beragam penduduknya. Baik dari segi suku, etnis, maupun agama. Mayoritas penduduknya, seperti tersaji dalam Tabel 2, merupakan pemeluk agama Islam, dengan komposisi sebesar 89\% dari seluruh penduduk yang ada. Sedangkan penduduk yang menganut agama Kristen memiliki komposisi sebesar 8\%, terbesar kedua setelah komposisi penduduk yang menganut agama Islam. Penduduk yang menganut agama Buddha memiliki komposisi tebesar ketiga, yaitu sebesar $8 \%$, sementara penduduk yang menganut agama Katolik memiliki komposisi sebesar $1 \%$. Penduduk yang menganut agama Hindu dan Khonghucu masing-masing memilki komposisi sebesar $0.1 \%$ dari seluruh penduduk yang ada.

\section{Pengelolaan dan Pendayagunaan Dana Zakat, Infak, dan Sedekah (ZIS)}

Lembaga-lembaga pengelola zakat, infak, dan sedekah (ZIS) yang beroperasi di Propinsi Riau dan terdaftar di Kantor Wilayah (Kanwil) 
Kementerian Agama Propinsi Riau sebagian besar merupakan perwakilan Badan Amil Zakat Nasional (Baznas) Popinsi dan Kabupaten/ Kota. Terdapat 12 Baznas tingkat kabupaten/kota dan 1 Baznas tingkat propinsi. Lembaga-lembaga zakat yang dikelola oleh masyarakat atau pihak swasta berjumlah lima buah. Lembaga-lembaga ini sebagian merupakan kantor perwakilan propinsi yang kantor pusatnya berada di Jakarta, dan hanya dua lembaga yang memiliki kantor pusat di Riau, yakni Lembaga Amil Zakat (LAZ) Swadaya Ummah di Pekanbaru dan LAZ Ibadurrahman di Duri, Bengkalis. Dalam penelitian ini, yang menjadi sampel pengelolaan dan pendistribusian zakat untuk usaha produktif adalah empat lembaga, yaitu BAZNAS Kota Pekanbaru, BAZNAS Kabupaten Siak, LAZ Swadaya Ummah Pekanbaru, dan LAZ Ibadurrahman Bengkalis.

Setiap lembaga zakat memiliki mekanisme dan manajemen pengelolaan dana ZIS yang berbeda. Bahkan masing-masing Baznas di setiap kabupaten/kota juga memiliki cara yang berbeda-beda dalam mengelola dana ZIS. Dua insitusi Baznas yang menjadi sasaran penelitian ini, penerimaan dana ZIS terbesar berasal dari para pegawai negeri sipil (PNS) di Satuan Kerja Perangkat Daerah (SKPD). Di Baznas Kab. Siak misalnya, komposisi penerimaan dari SKPD ini mencapai $64 \%$ dari seluruh sumber penerimaan yang ada. Sumber penerimaan terbesar kedua Baznas Kab. Siak adalah dari UPZ di setiap kecamatan, yang komposisinya sebesar $21 \%$. Sementara komposisi penerimaan dari non SKPD dan UPZ Kecamatan atau dari individu hanya mencapai $15 \%$.

Besarnya penerimaan dari SKPD di kedua lembaga Baznas ini tidak terlepas dari kebijakan serta kesungguhan setiap Kepala Daerah dalam mengelola dana ZIS. Hampir di setiap kabupaten/kota di Propinsi Riau, telah diterbitkan surat keputusan kepala daerah untuk bagi PNS di setiap SKPD untuk mengumpulkan dana ZIS mereka di masing-masing Baznas yang ada. Namun, tidak setiap kabupaten/kota memiliki keberhasilan yang sama. Bupati Kab. Siak contohnya, setiap tahunnya menggelar acara penerimaan ZIS dan beliau sendiri yang bertindak sebagai amil. ${ }^{64}$ 
Karenanya, tidak mengherankan jika penerimaan danaZIS di BaznasKab. Siak merupakan yang tertinggi di Propinsi Riau, yang hampir mencapai 9 miliar rupiah. Jumlah ini meningkat tajam jika dibanding tahun 2011 yang penerimaan dana ZIS hanya sebesar 450 juta rupiah. ${ }^{65}$

Jika penerimaan dana ZIS pada Baznas di setiap kabupaten/kota bergantung kepada kebijakan dan kesungguhan kepala daerah, yang disertai dengan kesungguhan para amil zakat mempromosikan pentingnya zakat, maka penerimaan dana ZIS pada lembaga amil zakat (LAZ) murni sangat bergantung pada kesungguhan, jejaring kerja, dan kreativitas para amil mempromosikan lembaga mereka. LAZ Ibadurrahman di Kab. Bangkalis misalnya, muzakki entitas yang mendonasikan dana ZIS mereka ke lembaga ini adalah karyawan PT Chevron. Karena pengurus LAZ Ibadurrahman banyak yang menjadi pegawai di perusahaan ini, maka mereka juga mudah mengajak rekan-rekan mereka mendonasikan sebagian penghasilan mereka ke lembaga ini. Sebagian besar penerimaan danaZIS di LAZIbadurrahman merupakan penyaluran dana ZIS dari karyawan perusahaan ini.

Sayangnya, dengan sistem seperti ini, maka saat terjadi banyak pemutusan hubungan kerja di perusahaan ini, seperti terjadi pada tahun 2016 ini, maka muncul kekhawatiran terjadi penurunan penerimaan dana ZIS oleh lembaga ini. Karenanya, sejak awal tahun 2016 pengurus LAZ Ibadurrahman memperluas jangkauan kerja untuk menjaring lebih banyak muzakki, terutama dari kalangan pengusaha dan petani sawit. Selain karyawan PT Chevron, muzakki yang mendonasikan danaZIS mereka ke LAZ Ibadurrahman adalah individu-individu yang beragam.

Jika LAZ Ibadurrahman memanfaatkan jejaring kerja para pengurusnya, maka LAZ Swadaya Ummah di Kota Pekanbaru benarbenar bekerja keras untuk menarik muzakki mau mendonasikan dana ZIS mereka ke lembaga ini. Sebagian besar muzakki yang menyerahkan pengelolaan dana ZIS mereka ke lembaga ini adalah individu. Hanya kelompok-kelompok usaha dalam skala kecil saja yang bekerja sama dengan mereka, dan sifatnya pun temporer. 
Persentase penyaluran dana ZIS pada setiap program di masingmasing lembaga zakat tidak menentu setiap tahunnya. Namun, yang bisa dipastikan bahwa bantuan untuk program konsumtif lebih besar dari program produktif. Besarnya bantuan untuk program konsumtif ini karena bantuan ini yang paling nyata dirasakan oleh mustahik dan memiliki tingkat kepentingan yang mendesak, terutama pada saat terjadi musibah dan kondisi mendesak (injury) lainnya. Pada tahun 2015 lalu misalnya, seluruh sumber daya yang dimiliki hampir seluruh lembaga zakat di Propinsi Riau terserap untuk membantu korban bencana kabut asap. Bahkan, beberapa mustahik yang telah mengikuti program zakat produktif dan mulai mapan dalam mengelola usaha mereka, ikut terdampak akibat musibah ini, dan kembali menjadi bagian dari mustahik yang diikutkan dalam program konsumtif.

Bantuan program produktif di masing-masing lembaga zakat bervariasi. Ada yang mengedepankan pendekatan usaha produktif individual, yang diterapkan di hampir semua lembaga, ada pula yang mengedepankan pendekatan kelompok usaha, meski ada juga yang berusaha mengkombinasikan kedua pendekatan ini. Ada yang menggunakan bentuk bantuan lepas, yang dilakukan oleh sebagian besar lembaga pengelola dana ZIS, ada yang masih menggunakan bantuan pinjaman modal usaha.

LAZ Ibadurrahman misalnya, sejak dua tahun belakangan lebih menggalakkan bantuan program bagi usaha kecil mandiri yang menggunakan dua pendekatan; usaha perorangan yang pembinaannya dilakukan secara berkelompok. Program ini merupakan program bantuan bagi kelompok usaha yang terdiri dari beberapa mustahik, biasanya terdiri dari 10 - 15 orang, yang menjalankan berbagai jenis usaha. Dengan bentuk program semacam ini, maka pemantauan kegiatan usaha dan penggunaan bantuan dapat diawasi. Setiap mustahik yang hendak ikut dalam program ini diharuskan membuka rekening bank, dan setiap bulan dari hasil usahanya harus disisihkan sebesar Rp. 10.000,- untuk tabungan pribadi, yang dipegang oleh pihak LAZ. Setiap akhir tahun 
program, hasil usaha yang disisihkan di rekening bank ini diberitahukan kepada mustahik.

Bantuan program produktif yang menggunakan model bantuan pinjaman modal usaha adalah program yang dikembangkan oleh LAZ Swadaya Ummah, yaitu Program Sentra Pemberdayaan Ekonomi (ProSPEK). Bentuk program yang berupa bantuan pinjaman ini demi menggiatkan para mustahik menjalankan usaha mereka. Sebab, jika diberikan bantuan lepas, seperti hasil evaluasi program sebelumnya, banyak mustahik yang tidak bertanggung jawab terhadap dana yang mereka peroleh. Dengan program ini, setiap pinjaman modal usaha yang diterima ditentukan jangka waktu pengembaliannya. Biasanya, pengembalian pinjaman dilakukan setiap satu minggu sekali. Selain mengembalikan bantuan pinjaman yang wajib dilakukan, pada setiap pengembalian dana, para mustahik ini dikenakan biaya pengembalian lebih sebagai bentuk infak dan sedekah mereka yang disalurkan kepada LAZ Swadaya Ummah. Pemberian bantuan dalam bentuk pinjaman ini juga mensyaratkan kesungguhan usaha yang dijalani. Artinya, mustahik yang diberi bantuan pinjaman usaha adalah mustahik yang sudah memiliki rintisan usaha.

Berbagai bentuk program bantuan untuk usaha produktif yang dikembangkan oleh setiap lembaga pengelola ZIS, belum dapat dikuantifikasi secara valid tingkat keberhasilannya. Di setiap lembaga pengelola ZIS yang menjadi sasaran penelitian menegaskan, bahwa tingkat keberhasilan program ekonomi produktif hanya bisa ditaksir berada di bawah $10 \%$ hingga $20 \%$. Keberhasilan ini pun hanya dilihat dari keberlanjutan usaha yang dijalani, belum sampai melihat perubahan taraf hidup mustahik yang mendapat bantuan usaha. Hal ini dikarenakan minimnya proses pendampingan atau pembinaan, pengawasan, dan evaluasi dari setiap program yang dikembangkan. Di hampir semua lembaga yang menjadi sasaran penelitian, jika bantuan usai diberikan, maka seperti telah terlepas lembaga tersebut dari kewajiban. Kewajiban 
lembaga hanya ada pada menilai apakah mustahik yang mengajukan atau diajukan layak disebut mustahik dan mendapat bantuan.

Setiap mustahik, pada akhirnya, mengembangkan sendiri cara mereka dalam mendayagunakan dana ZIS yang mereka peroleh. Kelompok Tani Mugi Berkah misalnya, yang merupakan kelompok usaha tani yang terdiri dari 5 orang mustahik binaan Baznas Kab. Siak. Kelompok usaha ternak ini diberi modal awal 9 ekor kambing pada tahun 2014, yang terdiri 8 betina dan 1 pejantan, setelah disurvey pengajuan mereka. Usai diberi modal beberapa ekor kambing ini, dan modal perlengkapan lain seperti obat-obatan ternak, mereka tak diberi pendampingan saat kambing-kambing mereka sakit atau mengalami masalah lainnya. Hal ini juga terjadi pada kelompok usaha tani lain maupun individual yang mendapat bantuan modal hewan ternak. Dengan ketekunan dan keuletan mereka, kini kambing-kambing mereka berkembang biak menjadi 19 ekor, dan sudah pernah dijual sebanyak 6 ekor. Jumlah petani yang bertahan dalam kelompok usaha tani ini kini hanya 3 orang, karena 2 orang lainnya tidak mampu bekerja sama. Adanya pecah kongsi akibat ketidakkompakan seperti niat awal berusaha pun tidak terpantau oleh pihak Baznas.

Beberapa mustahik yang berhasil bertahan maupun maju dalam menjalankan usaha atas bantuan dana ZIS biasanya juga sudah memiliki benih usaha dan keuletan tekad untuk bisa hidup mandiri dan menjadi lebih baik. Pak Armen, yang merupakan pendatang dari daerah Agam, Sumatera Barat sudah memiliki kemampuan membuat bakso hasil dari belajar kepada kawannya yang pedagang bakso di Bukittinggi. Pada tahun 2011 iamendapat bantuan dana usaha dari LAZ Ibadurrahman senilai 6 juta rupiah dalam bentuk gerobak dan bahan dagangan untuk berjualan bakso. Pada tahun 2012 ia sempat vakum akibat kurang laris dan gerobaknya rusak, dan bekerja sebagai pelayan di rumah makan padang. Beliau kemudian memulai lagi usaha dagang bakso pada tahun 2013 dengan suntikan modal 1 juta rupiah, setelah ditawari oleh salah seorang 
pengurus LAZ Ibadurrahman. Kini omzet hasil berjualan baksonyarerata mencapai 900 ribu rupiah perhari dan sudah mempekerjakan 1 orang pegawai dengan gaji 1.5 juta rupiah.

Hal yang sama juga dialami oleh Pak Alex Pulungan, mustahik yang mendapat bantuan dana usaha dari Baznas Kab. Siak. Beliau membuka usaha toko kelontong hanya bermodal meja untuk dagang di depan rumahnya. Pada tahun 2014ia dan istri mendapat bantuan modal usaha awal yang diterima sebesar 4.5 juta rupiah, yang digunakan untuk menambah modal barang dagangan dan membangun kios di sebelah rumahnya. Kini, kios toko kelontongnya tergolong maju dan barang dagangannya sudah bervariasi. Meski terlihat maju, namun omzet hasil penjualannya tidak terlalu besar, sebab banyak pelanggannya yang mengutang untuk memenuhi kebutuhan sehari-hari.Sebagian besar penduduk di sekitar rumah Pak Alex merupakan buruh harian lepas (BHL) perkebunan sawit, dengan tingkat pendapatan yang rendah. Sehingga, mau tidak mau hanya dengan strategi itulah Pak Alex dapat mempertahankan usahanya.

Jika hingga kini program-program pemberdayaan ekonomi produktif di setiap lembaga pengelola dana ZIS belum membuahkan hasil maksimal, bisa jadi karena belum ada perencanaan dan pelaksanaan program yang tertata secara sistematis. Bank Pembangunan Asia (ADB) menjelaskan bahwa, pemberdayaan dikatakan komprehensif jika memiliki karakteristik;

1. Berbasis lokal. Perencanaan dan pelaksanaannya dilakukan pada lokasi setempat dan melibatkan sumber daya lokal. Beberapa kasus kegagalan atau kemandekan mustahik mendayagunakan dana ZIS untuk ekonomi produktif adalah karena tidak tahu apa yang hendak mereka usahakan. Mereka masih pada taraf cobacoba melakukan usaha, dan usaha yang mereka lakukan tidak mempertimbangkan kebutuhan lokal setempat.

2. Berorientasi pada peningkatan kesejahteraan. Program-program pemberdayaan ekonomi produktif melalui pemberian bantuan 
dari dana ZIS selama ini masih berorientasi pada pemberian modal untuk kelangsungan usaha, belum mengarah pada bagaimana usaha produktif yang dilakukan mustahik dapat meningkatkan kesejahteraan mereka. Mengikuti semboyan beberapa lembaga zakat, mengubah mustahik menjadi muzakki. Beberapa mustahik yang diberi modal usaha beberapa ekor hewan ternak jauh dari kata sejahtera, sebab apa yang mereka usahakan tentu akan berbuah dalam waktu yang sangat lama.

3. Berbasis kemitraan. Kemitraan yang terjalin selama ini masih antara lembaga pengelola ZIS dengan mustahik, belum melibatkan berbagai ahli atau kalangan yang memiliki kemampuan tertentu, seperti kemampuan teknologi informasi, perencanaan keuangan, manajemen perdagangan, dan sebagainya.

4. Berlangsung secara holistik. Pemberdayaan dana ZIS untuk kegiatan ekonomi produktif bagi mustahik mestinya juga melihat permasalahan yang mengelilingi mustahik itu sendiri. Kasus Pak Alex Pulungan misalnya, yang tokonya dapat terus berlanjut dengan modal yang terus terhutang oleh pelanggan di sekitarnya karena mereka bekerja serabutan dengan penghasilan tak menentu.

5. Berkelanjutan. Yang kerap absen dari program pemberdayaan ekonomi produktif bagi mustahik adalah keberlanjutan program. Begitu bantuan telah disalurkan oleh lembaga pengelola ZIS, maka untung atau rugi usaha yang dijalankan menjadi tanggung jawab penuh mustahik. Proses pendampingan, monitoring, dan evaluasi masih belum menjadi agenda tetap di banyak lembaga pengelola ZIS. ${ }^{66}$

Pemberdayaan dana ZIS bagi para mustahik sejauh ini baru pada memberikan atau mengalihkan sebagian kekuasaan, kekuatan atau kemampuan dari masyarakat yang mampu (muzakki) kepada mustahik agar menjadi lebih berdaya. Sebuah proses primer dari upaya mengubah 
masyarakat untuk dapat mandiri. Proses pemberdayaan mustahik melalui dana ZIS sejauh ini belum sampai kepada apa yang diperkenalkan Paulo Freire sebagai konsientisasi (conscientization), yaitu proses pemahaman dan penumbuhan kesadaran terhadap situasi yang sedang terjadi, baik dalam kaitannya dengan relasi-relasi politik, ekonomi, dan sosial. Sebuah kondisi di mana mustahik atau masyarakat mampu menganalisis permasalahan yang ada di lingkungan mereka, sehingga mereka yang sudah mampu mandiri dan sejahtera melalui danaZIS ini memberi kebermanfaatan bagi lingkungan. ${ }^{67}$

\section{Kesimpulan}

Berdasarkan uraian hasil penelitian di atas, dapat ditarik kesimpulan, bahwa sebagian besar mustahik penerima bantuan untuk program ekonomi produktif belum mengalami peningkatan taraf hidup yang cukup baik atau sejahtera. Tingkat keberhasilan program ini di masing-masing lembaga zakat dapat ditaksir berada pada kisaran kurang dari $20 \%$ dari seluruh mustahik yang menerima bantuan pengembangan usaha produktif. Beberapa faktor yang menyebabkan belum terlalu berhasilnya program pemberdayaan dana ZIS untuk kegiatan ekonomi produktif adalah belum dilaksanakannya program pemberdayaan ekonomi produktif bagi mustahik secara menyeluruh dan berkelanjutan. Selain itu, minimnya daya juang mustahik dalam mengembangkan usaha (enterpreneurship). Banyak mustahik yang gagal mengembangkan usaha karena belum pernah sama sekali membuka usaha dan masih taraf coba-coba.Mustahik yang mampu bertahan hingga pada taraf mandiri secara ekonomi bahkan hingga sejahtera adalah mereka yang telah mengalami jatuh-bangun dan pahitnya kebangkrutan serta mau terus berusaha.

Upaya yang dilakukan para mustahik dalam mendayagunakan bantuan dari lembaga-lembaga zakat sebagian besar dilakukan secara intuitif. Belum ada program pemberdayaan yang 
berkelanjutan yang dilakukan oleh masing-masing lembaga zakat dalam pengembangan ekonomi produktif. Proses pendampingan yang melibatkan berbagai ahli sesuai bidang usaha yang dikembangkan mustahikmisalnya, pengawasanyang berkelanjutan terhadap perkembangan usaha mereka, dan evaluasi terhadap apa yang telah diusahakan mustahik belum menjadi agenda tetap di setiap lembaga zakat.

Muzakki yang menyalurkan dana ZIS mereka dapat dikelompokkan menjadi dua golongan, pertama adalah Muzakki yang menyalurkan dana ZIS ke lembaga zakat pemerintah atau Baznas lebih banyak pegawai negeri sipil (PNS) yang bekerja pada satuan kerja perangkat daerah (SKPD) setempat. Kedua, Muzakki yang menyalurkan dana ZIS mereka ke lembaga zakat yang dikelola masyarakat (lembaga amil zakat/LAZ) merupakan muzakki individual yang beragam atau perusahaan skala kecil, menengah, bahkan hingga skala besar.

Dari komposisi muzakki ini, dapat dikatakan bahwa penerimaan ZIS lembaga zakat pemerintah sangat bergantung kepada penyaluran dana ZIS yang dihimpun oleh PNS di setiap SKPD. Dari sisi inovasi pengumpulan dana ZIS di sebagian besar Baznas, kreativitas lembaga ini kurang menarik dibandingkan LAZ. Sementara lembaga zakat yang dikelola oleh masyarakat sangat bergantung pada kreativitas dan tingkat amanah mereka dalam mengelola danaZIS yang dihimpun dari masyarakat. 


\section{Daftar Pustaka}

Alterman, Jon B., Shireen Hunter, \& Ann L. Phillips. 2005. The Idea and Practice of Philanthropy in The Muslim World. USAID: The Muslim World Series.

Al-Zuhayly, Wahbah.2008(Cet. Ke-7). Zakat; Kajian Berbagai Mazhab. Bandung; Remaja Rosdakarya.

Badan Pusat Statistik. 2015. Profil Kemiskinan di Indonesia Maret 2015; Persentase Penduduk Miskin Maret 2015 Mencapai 11,22 Persen. Berita Resmi Statistik No. 86/09/Th.XVIII, 15 September 2015, Badan Pusat Statistik.

Badan Pusat Statistik, 2016. Profil Kemiskinan di Indonesia September 2015; Persentase Penduduk Miskin September 2015 Mencapai 11,13 Persen. Berita Resmi Statistik No. 05/01/Th.XIX, 04Januari 2016, Badan Pusat Statistik.

Badan Pusat Statistik (BPS) Provinsi Riau.2015. Riau dalam Angka 2015. Pekanbaru; BPS.

Balai Litbang Agama Jakarta. 2009. Zakat Produktif di Lembaga Pemerintahan BUMN.Jakarta: Balai Litbang Agama Jakarta.

Bamualim, Chaider S., \& Abubakar, Irfan. 2005. Revitalisasi Filantropi Islam; Studi Kasus Lembaga Zakat dan Wakaf di Indonesia.Jakarta: Pusat Bahasa dan Budaya UIN Jakarta \& Ford Foundation.

Beik, IrfanSyauqi.2009. Analisis Peran Zakat dalam Mengurangi Kemiskinan; Studi Kasus Dompet Dhuafa Republika.Jurnal Pemikiran dan Gagasan, Vol. II, 2009.

Beik, IrfanSyauqi.2010. Peran Zakat Mengentaskan Kemiskinan dan Kesenjangan.Iqtishodia; Jurnal Ekonomi Islam Republika, Kamis 29 Juli 2010, hal. 5. 
Department of Economic and Social Affairs (DESA) Population Division. 2015. World Population Prospects The 2015 Revision; Key Findings and Advance Tables. New York: United Nations.

Direktorat Pemberdayaan Zakat.2015. Panduan Pengembangan Usaha bagi Mustahik.Jakarta; Direktorat Pemberdayaan Zakat, Ditjen Bimas Islam Kemenag RI.

Gaus AF., Ahmad.2008. Filantropi dalam Masyarakat Islam.Jakarta; Elex Media Komputindo.

Hassan, Riaz. 2007. Giving and Gaining; Philanthropy and Social Justice in Muslim Sicieties. Lahore Journal of Policy Studies, Vol. 1 No. 1, June 2007, p. 25-34.

Indiyanto, Agus.2013. Agama di Indonesia dalam Angka; Dinamika Demografis Berdasarkan Sensus Penduduk Tahun 2000 dan 2010. Yogyakarta; CRCS.

Kompas. 2016. Ketimpangan; Kemiskinan Sepanjang Hayat Keluarga Erni.18 Januari 2016, hal.1 \& 15.

Latief, Hilman.2010. Melayani Umat; Filantropi Islam dan Ideologi Kesejahteraan Kaum Modernis.Jakarta: Gramedia Pustaka Utama.

Latief, Hilman.2012. Filantropi Islam dan Aktivisme Berbasis Pesantren di Pedesaan.Afkaruna; Jurnal Ilmu-ilmu Keislaman.Vol. 8 No. 1, Januari-Juni 2008, hal.42-63.

Latief, Hilman.2013. Agama dan Pelayanan Sosial; Interpretasi dan Aksi Filantropi dalam Tradisi Muslim dan Kristen di Indonesia.Jurnal Religi Vol. IX No. 2, Juli 2013; 174-189.

Lord, John, \& Peggy Hutchison.1993. The Process of Empowerment; Implications for Theory and Practice.Canadian Journal of Community Mental Health. Page 5 - 22.

Makhrus, Utami, \&Restu Firda. 2015. Peran Filantropi Islam dalam Pemberdayaan Masyarakat di Kabupaten Banyumas.Kumpulan 
Makalah Seminar Nasional; Hasil-hasil Penelitian dan Pengabdian LPPM Universitas Muhammadiyah Purwokerto, Sabtu 26 September 2015, hal.175-184.

Mardikanto, Totok \& Poermoko Soebiato. 2012. Pemberdayaan Masyarakat dalam Perspektif Kebijakan Publik.Bandung: Alfabeta.

Prihatna, Andi Agung.2005. Filantropi dan Keadilan Sosial di Indonesia. Dalam Chaider S. Bamualim\&Irfan Abubakar (ed.), 2005.Revitalisasi Filantropi Islam; Studi Kasus Lembaga Zakat dan Wakaf di Indonesia. Jakarta: Pusat Bahasa dan Budaya UIN Syarif Hidayatullah Jakarta.

Public Interest Research and Advocacy Center (PIRAC). 2002.Investing in Ourselves; Giving and Fund Raising in Indonesia. Manila: Asian Development Bank.

Purwakananta, M. Arifin, dkk.2010. Peta Kemiskinan; Data Mustahik, Muzakki, dan Potensi Pemberdayaan Indonesia.Ciputat: Dompet Dhuafa.

Puslitbang Kehidupan Keagamaan.2015. Eksistensi Organisasi Pengelola Zakat (OPZ) Pasca Judicial Review Undang-undang Nomor 23 Tahun 2011. Makalah disampaikan pada Seminar Hasil Penelitian di Hotel Balairung Jakarta, 27 Nopember 2015.

Qardawi, Yusuf.2007(Cet. Ke-10). Hukum Zakat. Bogor; Pustaka Litera Antar Nusa dan BAZIS DKI Jakarta.

Soekanto, Soerjono.2007. Sosiologi; Suatu Pengantar (edisi baru ke-41). Jakarta: RajaGrafindo Persada.

Sudewo, Erie.2008. Politik ZISWAF; Kumpulan Esei.Jakarta; UI Press dan CID Dompet Dhuafa.

Suryahadi. 2010.Review of The Government's Poverty Reduction Strategies, Policies, Programs in Indonesia. Jakarta: The SMERU Research Institute.

Tamin, Imron Hadi. 2011. Peran Filantropi dalam Pengentasan 
Kemiskinan.Jurnal Sosiologi Islam, vol. 1 No. 1, hal 35 - 58, 2011.

Widyawati. 2011. Filantropi Islam dan Kebijakan Negara Pasca Orde Baru;

Studi tentang Undang-undang Zakat dan Undang-undang Wakaf. Bandung: Arsad Press.

Zubaedi. 2013. Pengembangan Masyarakat; Wacana dan Praktik. Jakarta: Kencana Prenada Media Group.

Website

Badan Pusat Statistik.2010. Data Sensus Penduduk 2010.Didapat dari http://sp2010.bps.go.id/index.php/site/tabel?tid=321, pada 13 Januari 2016.

Lausch, Heather.2011. Literature Review: Theories of Empowerment.Didapat dari http://villageearth.org/pages/village-earth-blog/literaturereview-theories-of-empowerment pada 3 April 2013.

Republika.2010. Survei; Zakat Kurangi Kemiskinan.Didapat dari http://khazanah.republika.co.id/berita/dunia-islam/islamnusantara/10/12/22/153705-survei-zakat-kurangi-kemiskinan, pada 13 Januari 2016.

Republika.2011. Presiden: Zakat Jalur Ketiga Kurangin Kemiskinan.Didapat dari http://www.republika.co.id/berita/dunia-islam/islamnusantara/11/03/18/170476-presiden-zakat-jalur-ketiga-kurangikemiskinan, pada 14 Januari 2016.

Republika.2012. Ini Alasan Zakat Belum Optimal Kurangi Kemiskinan. Didapat dari http://www.republika.co.id/berita/nasional/ umum/12/01/30/lylzuz-ini-alasan-zakat-belum-optimal-kurangikemiskinan, pada 13 Januari 2016.

van der Schaar, Richard. 2015. Kemiskinan di Indonesia. Didapat dari http:// www.indonesia-investments.com/id/keuangan/angka-ekonomimakro/kemiskinan/item301, pada 14 Januari 2016. 


\section{Endnotes}

1. Department of Economic and Social Affairs (DESA) Population Division. World Population Prospects The 2015 Revision; Key Findings and Advance Tables. New York: United Nations, 2015, hal. 29.

2. Badan Pusat Statistik (BPS), 2010. Data Sensus Penduduk 2010. Didapat dari http://sp2010.bps.go.id/index.php/site/tabel?tid=321, pada 13 Januari 2016.

3. Soekanto, Soerjono. Sosiologi; Suatu Pengantar (edisi baru ke-41). Jakarta: RajaGrafindo Persada, 2007, hal. 338

4. Indiyanto, Agus. Agama di Indonesia dalam Angka; Dinamika Demografis Berdasarkan Sensus Penduduk Tahun 2000 dan 2010. Yogyakarta; CRCS, 2013, hal. 12.

5. Badan Pusat Statisti. Profil Kemiskinan di Indonesia September 2015; Persentase Penduduk Miskin September 2015 Mencapai 11,13 Persen. Berita Resmi Statistik No. 05/01/Th.XIX, 04Januari 2016, Badan Pusat Statistik, 2016, hal. 1-3.

6. van der Schaar, Richard, 2015. Kemiskinan di Indonesia. Didapat dari http:// www.indonesia-investments.com/id/keuangan/angka-ekonomi-makro/ kemiskinan/item301, pada 14 Januari 2016.

7. Suryahadi. Review of The Government's Poverty Reduction Strategies, Policies, Programs in Indonesia. Jakarta: The SMERU Research Institute, 2010, hal. 28.

8. Suryahadi. Review of The Government's Poverty Reduction Strategies, Policies, Programs in Indonesia. Jakarta: The SMERU Research Institute, 2010, hal. 28.

9. Beik, IrfanSyauqi. Analisis Peran Zakat dalam Mengurangi Kemiskinan; Studi Kasus Dompet Dhuafa Republika.Jurnal Pemikiran dan Gagasan, Vol. II, 2009, hal. 1.

10. Republika, 2011.Presiden: Zakat Jalur Ketiga Kurangin Kemiskinan. Didapat dari http://www.republika.co.id/berita/dunia-islam/islamnusantara/11/03/18/170476-presiden-zakat-jalur-ketiga-kurangikemiskinan, pada 14 Januari 2016. 
11. Republika,2010.Survei;ZakatKurangiKemiskinan.Didapatdarihttp://khazanah. republika.co.id/berita/dunia-islam/islam-nusantara/10/12/22/153705-surveizakat-kurangi-kemiskinan, pada 13 Januari 2016.

12. Hassan, Riaz. Giving and Gaining; Philanthropy and Social Justice in Muslim Sicieties. Lahore Journal of Policy Studies, Vol. 1 No. 1, June 2007, p. 25-34.

13. Hassan, Riaz. Giving and Gaining; Philanthropy and Social Justice in Muslim Sicieties. Lahore Journal of Policy Studies, Vol. 1 No. 1, June 2007, p. 25-34.

14. Widyawati.Filantropi Islam dan Kebijakan Negara Pasca Orde Baru; Studi tentang Undang-undang Zakat dan Undang-undang Wakaf. Bandung: Arsad Press, 2011, hal. 8.

15. Bamualim, Chaider S.\& Abubakar, Irfan.Revitalisasi Filantropi Islam; Studi Kasus Lembaga Zakat dan Wakaf di Indonesia.Jakarta: Pusat Bahasa dan Budaya UIN Syarif Hidayatullah Jakarta. 2005, hal. Viii.

16. Latief, Hilman. Filantropi Islam dan Aktivisme Berbasis Pesantren di Pedesaan.Afkaruna; Jurnal Ilmu-ilmu Keislaman.Vol. 8 No. 1, Januari-Juni 2008, hal. 42-63.

17. Makhrus\&Utami, Restu Firda.Peran Filantropi Islam dalam Pemberdayaan Masyarakat di Kabupaten Banyumas.Kumpulan Makalah Seminar Nasional; Hasil-hasil Penelitian dan Pengabdian LPPM Universitas Muhammadiyah Purwokerto, Sabtu 26 September 2015, hal. 175-184.

18. Widyawati.Filantropi Islam dan Kebijakan Negara Pasca Orde Baru; Studi tentang Undang-undang Zakat dan Undang-undang Wakaf. Bandung: Arsad Press, 2011, hal. 187.

19. Public Interest Research and Advocacy Center (PIRAC). Investing in Ourselves; Giving and Fund Raising in Indonesia. Manila: Asian Development Bank, 2002, 23.

20. Purwakananta, Arifin, dkk.. Peta Kemiskinan; Data Mustahik, Muzakki, dan Potensi Pemberdayaan Indonesia.Ciputat: Dompet Dhuafa, 2010, 11-17.

21. Balai Litbang Agama Jakarta, 2009.Zakat Produktif di Lembaga Pemerintahan BUMN.Jakarta: Balai Litbang Agama Jakarta. 
22. Puslitbang Kehidupan Keagamaan. Eksistensi Organisasi Pengelola Zakat (OPZ) Pasca Judicial Review Undang-undang Nomor 23 Tahun 2011. Makalah disampaikan pada Seminar Hasil Penelitian di Hotel Balairung Jakarta, 27 Nopember 2015.

23. Lausch, Heather, 2011. Literature Review: Theories of Empowerment.Didapat dari http://villageearth.org/pages/village-earth-blog/literature-reviewtheories-of-empowerment pada 3 April 2013.

24. Zubaedi, Pengembangan Masyarakat; Wacana dan Praktik. Jakarta: Kencana Prenada Media Group, 2013, hal. 73.

25. Lord, John, \& Peggy Hutchison.The Process of Empowerment; Implications for Theory and Practice.Canadian Journal of Community Mental Health.1993, p. $5-22$.

26. Lausch, Heather, 2011. Literature Review: Theories of Empowerment.Didapat dari http://villageearth.org/pages/village-earth-blog/literature-reviewtheories-of-empowerment pada 3 April 2013.

27. Zubaedi, Pengembangan Masyarakat; Wacana dan Praktik. Jakarta: Kencana Prenada Media Group, 2013, hal. 76.

28. Lausch, Heather, 2011. Literature Review: Theories of Empowerment.Didapat dari http://villageearth.org/pages/village-earth-blog/literature-reviewtheories-of-empowerment pada 3 April 2013.

29. Lord, John, \& Peggy Hutchison.The Process of Empowerment; Implications for Theory and Practice.Canadian Journal of Community Mental Health.1993, p. $5-22$.

30. Zubaedi, Pengembangan Masyarakat; Wacana dan Praktik. Jakarta: Kencana Prenada Media Group, 2013, hal. 75.

31. Prihatna, Andi Agung. Filantropi dan Keadilan Sosial di Indonesia.Dalam Chaider S. Bamualim\&Irfan Abubakar (ed.), 2005.Revitalisasi Filantropi Islam; Studi Kasus Lembaga Zakat dan Wakaf di Indonesia.Jakarta: Pusat Bahasa dan Budaya UIN Syarif Hidayatullah Jakarta.2005,hal. 3. Bandingkan juga denganGaus AF, Filantropi dalam Masyarakat Islam.Jakarta; Elex Media Komputindo.2008,hal. 1; Latief, Hilman. Melayani Umat; Filantropi Islam dan 
Ideologi Kesejahteraan Kaum Modernis.Jakarta: Gramedia Pustaka Utama.2010, hal.34; dan Widyawati, Filantropi Islam dan Kebijakan Negara Pasca Orde Baru; Studi tentang Undang-undang Zakat dan Undang-undang Wakaf. Bandung: Arsad Press, 2011, hal. 18.

32. Gaus AF., Filantropi dalam Masyarakat Islam. Jakarta; Elex Media Komputindo.2008,hal.4. Bandingkan juga denganWidyawati, Filantropi Islam dan Kebijakan Negara Pasca Orde Baru; Studi tentang Undang-undang Zakat dan Undang-undang Wakaf. Bandung: Arsad Press, 2011, hal. 18.

33. Prihatna, Filantropi dan Keadilan Sosial di Indonesia.Dalam Chaider S. Bamualim\&Irfan Abubakar (ed.), 2005.Revitalisasi Filantropi Islam; Studi Kasus Lembaga Zakat dan Wakaf di Indonesia.Jakarta: Pusat Bahasa dan Budaya UIN Syarif Hidayatullah Jakarta.2005,hal.3; danLatief, Hilman. Melayani Umat; Filantropi Islam dan Ideologi Kesejahteraan Kaum Modernis.Jakarta: Gramedia Pustaka Utama.2010, hal. 34.

34. Latief, Hilman. Melayani Umat; Filantropi Islam dan Ideologi Kesejahteraan Kaum Modernis.Jakarta: Gramedia Pustaka Utama.2010, hal.34-36;Widyawati, Filantropi Islam dan Kebijakan Negara Pasca Orde Baru; Studi tentang Undangundang Zakat dan Undang-undang Wakaf. Bandung: Arsad Press, 2011, hal. 19.

35. Widyawati.Filantropi Islam dan Kebijakan Negara Pasca Orde Baru; Studi tentang Undang-undang Zakat dan Undang-undang Wakaf. Bandung: Arsad Press, 2011, hal. 19-20.

36. Latief, Hilman. Melayani Umat; Filantropi Islam dan Ideologi Kesejahteraan Kaum Modernis.Jakarta: Gramedia Pustaka Utama.2010, hal. 34

37. PIRAC.Investing in Ourselves; Giving and Fund Raising in Indonesia. Manila: Asian Development Bank, 2002, p.8.

38. Tamin, Imron Hadi.Peran Filantropi dalam Pengentasan Kemiskinan.Jurnal Sosiologi Islam, vol. 1 No. 1, 2011, hal 35 - 58.

39. Prihatna, Filantropi dan Keadilan Sosial di Indonesia.Dalam Chaider S. Bamualim\&Irfan Abubakar (ed.), 2005.Revitalisasi Filantropi Islam; Studi Kasus Lembaga Zakat dan Wakaf di Indonesia.Jakarta: Pusat Bahasa dan Budaya UIN Syarif Hidayatullah Jakarta.2005,hal. 4. 
40. Prihatna, Filantropi dan Keadilan Sosial di Indonesia.Dalam Chaider S. Bamualim\&Irfan Abubakar (ed.), 2005.Revitalisasi Filantropi Islam; Studi Kasus Lembaga Zakat dan Wakaf di Indonesia.Jakarta: Pusat Bahasa dan Budaya UIN Syarif Hidayatullah Jakarta.2005,hal. 4-5.

41. Gaus AF., Ahmad. Filantropi dalam Masyarakat Islam.Jakarta; Elex Media Komputindo. 2008, hal. 3; Alterman, Jon B., Shireen Hunter, \& Ann L. Phillips. The Idea and Practice of Philanthropy in The Muslim World.USAID: The Muslim World Series, 2005, p. 3.

42. Hassan, Riaz. Giving and Gaining; Philanthropy and Social Justice in Muslim Societies. Lahore Journal of Policy Studies, Vol. 1 No. 1, June 2007, p. 25-34.

43. Prihatna, Filantropi dan Keadilan Sosial di Indonesia.Dalam Chaider S. Bamualim\&Irfan Abubakar (ed.), 2005.Revitalisasi Filantropi Islam; Studi Kasus Lembaga Zakat dan Wakaf di Indonesia.Jakarta: Pusat Bahasa dan Budaya UIN Syarif Hidayatullah Jakarta. 2005, hal. 6.

44. Gaus AF., Ahmad. Filantropi dalam Masyarakat Islam.Jakarta; Elex Media Komputindo. 2008, hal. 10

45. Hassan, Riaz.Giving and Gaining; Philanthropy and Social Justice in Muslim Societies. Lahore Journal of Policy Studies, Vol. 1 No. 1, June 2007, p. 25-34.

46. Prihatna, Filantropi dan Keadilan Sosial di Indonesia.Dalam Chaider S. Bamualim\&Irfan Abubakar (ed.), 2005.Revitalisasi Filantropi Islam; Studi Kasus Lembaga Zakat dan Wakaf di Indonesia.Jakarta: Pusat Bahasa dan Budaya UIN Syarif Hidayatullah Jakarta. 2005, hal. 6.

47. Qardawi, Yusuf. Hukum Zakat (Cet. Ke-10). Bogor; Pustaka Litera Antar Nusa dan BAZIS DKI Jakarta, 2007, hal. 34.

48. Qardawi, Yusuf. Hukum Zakat (Cet. Ke-10). Bogor; Pustaka Litera Antar Nusa dan BAZIS DKI Jakarta, 2007, hal. 34-35.

49. Al-Zuhayly (2008; 83-85)

50. Qardawi, Yusuf. Hukum Zakat (Cet. Ke-10). Bogor; Pustaka Litera Antar Nusa dan BAZIS DKI Jakarta, 2007, hal. 510.

51. Qardawi, Yusuf. Hukum Zakat (Cet. Ke-10). Bogor; Pustaka Litera Antar Nusa dan BAZIS DKI Jakarta, 2007, hal. 96. 
52. Beik (dalam Republika, 2012)

53. Gaus AF., Ahmad. Filantropi dalam Masyarakat Islam.Jakarta; Elex Media Komputindo. 2008, hal.Viii.

54. Republika, 2011.Presiden: Zakat Jalur Ketiga Kurangin Kemiskinan. Didapat dari http://www.republika.co.id/berita/dunia-islam/islamnusantara/11/03/18/170476-presiden-zakat-jalur-ketiga-kurangikemiskinan, pada 14 Januari 2016.

55. Republika, 2012.Ini Alasan Zakat Belum Optimal Kurangi Kemiskinan. Didapat dari http://www.republika.co.id/berita/nasional/umum/12/01/30/ lylzuz-ini-alasan-zakat-belum-optimal-kurangi-kemiskinan, pada 13 Januari 2016.

56. Sudewo, Erie. Politik ZISWAF; Kumpulan Esei.Jakarta; UI Press dan CID Dompet Dhuafa, 2008, hal. 141-143.

57. Direktorat Pemberdayaan Zakat. Panduan Pengembangan Usaha bagi Mustahik. Jakarta; Direktorat Pemberdayaan Zakat, Ditjen Bimas Islam Kemenag RI.2015, hal. 34-61.

58. Badan Pusat Statistik (BPS) Provinsi Riau.Riau dalam Angka 2015. Pekanbaru; BPS, 2015, hal. 3 - 9

59. Badan Pusat Statistik (BPS) Provinsi Riau.Riau dalam Angka 2015. Pekanbaru; BPS, 2015, hal.55 - 56.

60. Jumlah yang digunakan dalam tulisan ini adalah jumlah versi penulis, yaitu yang tertulis pada kolom jumlah kedua. Jumlah yang disajikan oleh BPS, seperti tersaji pada kolom pertama, terdapat kesalahan penghitungan setelah dilakukan penghitungan ulang oleh penulis.

61. Badan Pusat Statistik. Profil Kemiskinan di Indonesia September 2015; Persentase Penduduk Miskin September 2015 Mencapai 11,13 Persen. Berita Resmi Statistik No. 05/01/Th.XIX, 04Januari 2016, Badan Pusat Statistik. 2016, hal. 7.

62. Badan Pusat Statistik (BPS) Provinsi Riau.Riau dalam Angka 2015. Pekanbaru; BPS, 2015, 9.

63. Badan Pusat Statistik (BPS) Provinsi Riau.Riau dalam Angka 2015. Pekanbaru; BPS, 2015, hal. 9 \& 22. 
64. Wawancara dengan SekrertarisKatua Harian BaznasKab. Siak, 12 Pebruari 16.

65. Laporan Tahunan Baznas Kabupaten Siak 2014.

66. Zubaedi, Pengembangan Masyarakat; Wacana dan Praktik. Jakarta: Kencana Prenada Media Group, 2013, hal. 76. .

67. Zubaedi, Pengembangan Masyarakat; Wacana dan Praktik. Jakarta: Kencana Prenada Media Group, 2013, hal. 75. 